\title{
Influence of Selected Work Related Variables on Occupational Stress Among Teachers in Kenya
}

\author{
Lucy Omwenga* Dr. Judith Owaa \\ School Of Education, Jaramogi Oginga Odinga University of Science and Technology. \\ PO BOX 210, BOND0, Kenya
}

\begin{abstract}
Occupational stress is a universal phenomenon that manifests itself among workers as a result of pressures originating from within or outside the work place. Work stress has had negative effects on performance and service delivery among workers and can therefore be expensive for organizations as it adversely affects organizational performance and productivity. Globally, teaching has been ranked the second most stressful job after ambulance driving and incidences of teachers experiencing occupational stress have been reported in Borabu Sub County. Given the important role education plays in shaping society, the pivotal roles played by teachers globally and in Borabu SubCounty cannot be over stated. Majority of teachers confess that they would opt for an alternative profession given an opportunity, a situation witnessed by a substantive number of teachers who get newly employed or are always ready to transfer to other professions. Some studies on teachers' occupational stress have concentrated on factors causing or contributing to stress or effects of occupational stress on performance among teachers but have not investigated the influence of selected work related variables on occupational stress among secondary school teachers. The purpose of the present study was to investigate the Influence of Selected Work RelatedVariables on Occupational Stress among Teachers in Public Secondary Schools in Borabu-Sub County of Nyamira County. The main objective of the study was to determine the influence of role overload on occupational stress among public secondary school teachers. The study was anchored on Person Environment Fit Theory of Caplan. The study employed convergent parallel research design within mixed method approach. The population of the study comprised 212 public high school teachers, 21 Principals, and 3 Education Officers. Saturated sampling was used to obtain a sample size of 212 teachers, 21 Principals and 3 Education Officers of Borabu Sub County, Nyamira County, Kenya. Occupational stress questionnaire was used to collect quantitative data from teachers while qualitative data was collected using interviews to Principals and Education Officers. Descriptive statistics and correlational analysis were used to analyze quantitative data while qualitative data was analyzed using thematic framework. Validity of the instruments was ensured by seeking expert judgement from university psychology lecturers. Reliability of the instruments was determined using internal consistency with an index of 0.70 reported. The study results revealed that high school teachers of Borabu Sub County have a significant amount of role overload at $r=0.647$. The study established that co and extracurricular activities plummeted the teachers work. The study recommended that teachers, school Principals, Teacher Counselors, other Education stake holders and policy makers need to apply adjustment interventions for occupational stress reduction among educators.
\end{abstract}

Keywords: Influence, Occupational, Stress, work

DOI: $10.7176 / \mathrm{JEP} / 12-30-07$

Publication date:October $31^{\text {st }} 2021$

\section{Introduction}

\section{Background of the Study}

Occupational stress may be defined as the experience of unpleasant negative emotions such as tension, anxiety, frustration, anger and depression resulting from aspects of work (Salami, 2010). While stress is necessary and positive it can also be negative and harmful. Occupational stress arises from demanding and unreasonable physical and mental situations upon the adaptive abilities of the mind and the body called stressors. This significantly affects performance and service delivery of workers (Ngari, Ndungu, Mwonya, Mumiukha, Kariuki, 2013). Occupational stress is a term used to define on going stress that is related to the workplace and may have to do with the responsibilities associated with the work itself or be caused by conditions that are based at the employer's environment or personality conflicts. As with other forms of tension, occupational stress can eventually affect both physical and emotional well being if not managed effectively (Kaur, 2011). It is against this background that the study investigated influence of selected work related variables on occupational stress among teachers of public secondary schools in Kenya. According to Kaur (2011) the teaching profession had a very prestigious place among all professions. A teacher was a kingpin in the entire system of education. Almost all cultures of the civilized world have considered their teachers in a very high esteem. They are often referred as Master, Mentor or Guru. Most thinkers and philosophers of the past are still remembered because they had disciples and students. Times have changed and the societies and cultures have drastically diversified, but the tasks of a teacher are primarily the same, which is the transfer of knowledge to the next generation. With change in cultural norms and traditions in the societies, there has been a drastic change in the expectations from the teacher. Some of these changes have limited 
the measures which a teacher in the past could exercise in disciplining a student and some have put additional burden on teachers in respect of their preparation of lessons and adopting and maintaining their teaching styles. Moreover, teaching has now become a very demanding occupation with a lot of stress for a teacher who has a lot of deadlines to meet and a lot of responsibilities to shoulder alongside the primary role of teaching students. Primarily the role and responsibility of a teacher is multitasking in the present day school system. With the change in the type of teaching culture, and added managerial responsibilities for teachers to include planning and executing instructional lessons, assessing students based on the curriculum and communicating with parents, there are other extra duties that contribute to the teacher's stress all over the world that include; lesson planning and teaching, accountability for student performance, classroom management and discipline, supervisory role and conducting and monitoring extra curricular activities (Kaur, 2011). The goal of education in developing countries, including Kenya is to equip students with new skills, tacit knowledge, cultures, attitudes, behaviors and innovative ways of solving day to day problems in life. Education is aimed at supplying the economy with human capital that can convert efficiently other resources into output of high value for quality life (UNESCO, 2012). To attain quality education for sustainable development, the teacher as the core instiller of knowledge should be well motivated, healthy and satisfied with the job for excellent performance (KUPPET, 2015). McMahon (2010) study on work related stress among teachers in the USA indicated that stress among teachers has caused a dysfunction among them and even led others to move out of the profession. The researcher further highlights that this is caused by demands to meet government teaching targets. These demands are associated with employment tasks at the work place such as educational institutions (Komal, 2012). The role of a teacher demands the highest qualities of dedication and commitment so as to play a key role in the attainment of educational goals as set out by society (Sichambo, Maragia \& Simiyu, 2012).

In the course of discharging responsibilities, the teacher acts as an instructor, motivator, examiner, guide and counselor to mould the future work force of any nation. Teachers thus occupy the top most position in the academic and professional educational pyramid from where they bring constructive, productive and quality education in society (Madhu \& Manju, 2013).

A high quality teaching staff is the cornerstone of a successful education system which elevates the teacher as a key variable for student achievement through the daily teacher - student interaction that forms the centre of the education process. However, the teaching profession is continuously beset with several problems among them is occupational stress among its human resource, a major hindrance in academic productivity. Developed and developing countries are finding it difficult to counter occupational stress among teachers' (Jerotich, Jeruto \& Chemwei, 2014). Ozturk, (2011) study in Australia observed that along with servicemen, social workers and linguists, teachers have surfaced at the start of the new millennium as the most afflicted with rising levels of occupational stress. Teachers play a significant role in the development of countries by educating new generations and that they are important factors in the education process. Therefore, ensuring their satisfaction by improving their working conditions in schools may positively affect their physiological and psychological wellbeing and thus ensure improved educational productivity (Ozturk, 2011). Mohd, (2014) posted that occupational stress is one of the most critical factors for the future success of education and schools in India. This study was on occupational stress amongst teachers of professional colleges of Education in Jammu province, India and not the influence of selected work related variables on occupational stress among secondary school teachers in Kenya which has been dealt with in the current study. The study further posts that teaching is a complex and demanding work and there is a daily need for teachers to fully engage in that work with not only their heads but also their hearts. Moreover, other professions such as professional programmers, company executives as well as in sports have revealed that their stress levels are lower than stress levels among teachers.

Other than occupational stress, these studies have also established that teachers suffer from burnout (Komal, 2012). Not surprisingly, therefore, teaching has been identified as being associated with high to very high levels of occupational stress (Mohd, 2014). Buckley (2011) studied on the wellbeing of Newzealand teachers, the relationship between health, stress, job demands and teacher efficacy found that over $39 \%$ of teachers considered teaching to be either very stressful or extremely stressful. This means that most teachers experience stress. Shernoff, Mehta, Attikins, Torf and Spencer (2011), conducted a qualitative study on the sources and impact of stress among twenty urban teachers of three low-performing elementary schools located in high poverty urban neighbourhoods in a large Midwestern city at USA. The study concluded that lack of resources, excessive workload, school-level disorganization, managing behavior problems and accountability policies are significant sources of stress for urban teachers. Siddiqui (2012) in a study of occupational stress in teachers, a comparative study of public and private schools in Hyderabad in India found that it was a fact that female teachers working in public schools as compared to working in private schools lack resources like advanced technologies. Lacking such basic resources could be considered a contributing factor in their stress level. On a similar note, Endale (2019) did a study on teachers' organizational commitment to secondary schools in Addis Ababa, Ethiopia and the study identified teachers as playing big roles in executing the goals of education. The major findings from the study were public secondary teachers low speaking of affective and normative but their continuance commitment was 
encouraging and senior and experienced teachers specifically showed low commitment level. Therefore the school leaders, teachers unions and concerned bodies need to devise new ways of refreshing senior teachers and give responsibilities to participating teachers in the decision making process. Ncube and Tshabalala (2013), studied work stress among 200 teacher in Zimbabwe and found that most of the teachers perceived poor pay, work overload, bad school management, role overload and large class sizes as the major causes of stress in their work. They also reported lack of resources for the job, bad social climate, low social status of teachers, anxiety, over evaluation and lack of social support from colleagues, particularly senior colleagues also significantly affected the stress levels of teachers and the least qualified teachers were affected by self-defeating beliefs, unacceptable people's behavior, lack of parental support, fear of conflict, lack of job stability and security as well as career development. Waititu (2012) conducted a study in Limuru District which indicated that many teachers were leaving the profession because of poor remuneration for greener financial pastures. The study observed that teaching was a much sought after profession, yet growing opportunities and well-paying career alternatives are making it difficult to attract and retain highly qualified teachers as the job pressures far outweigh the benefits of working in such a service organization. Related studies in by Wangeri and Okello (2014) asserted that work stress and burnout are related to negative effects on mental and physical health of the affected workers. Teachers experiencing work stress are more likely than their non-stressed colleagues to suffer job dissatisfaction, lowered productivity, absenteeism, lowered emotional and physical health, active participation in strikes, low morale, experience of tiredness and turnover intentions. When the teachers suffer from occupational stress, the students they teach are affected negatively as they may not have pleasant experiences with the teachers and thus they may not pass important examinations and their future prospects are compromised. In addition, Kitengo and Ngeno (2009) conducted a study which established that teachers working in friendlier environments like the private schools may enjoy more structured work environments and higher pay which is likely to translate to less occupational stress. In contrast, teachers working in public schools and who have heavy workload, less friendly working environment with less attractive pay may experience higher levels of occupational stress than their counterparts in the private schools (Kitenga, 2009; Ngeno, 2007). Similarly, Emoja (2016) conducted a study on job satisfaction and teacher turnover intention in secondary schools in Kakamega and found that approximately 600 teachers leave the teaching profession annually and has led to an increase in student teacher ratio where some classrooms have about 70 students posing a worrying situation in the profession. This has resulted to reduced individualized attention to slow learners leading to a decline in the quality of education. Further, the researcher contends that most teachers are stressed with their jobs (Waititu, 2012; Njiru, 2014). Satisfied employees hardly think of leaving their current jobs (Zahra et al, 2013). In the same vein, Ogolla, Aloka and Raburu (2016) sought to examine the relationship between locus of control and stress management among high school Principals in Homa Bay County of Kenya. The study noted that principals with internal locus of control had the highest score of stress. The ANOVA results indicated that there was a statistically significant difference $(\mathrm{p}=.05)$ in stress management scores for locus of control $[\mathrm{F}(2$, $165)=356, p<.05]$. In the same breath, Muguongo, Muguna and Muriithi (2015) study on effects of compensation on job satisfaction among secondary school teachers in Maara Sub-County of Tharaka Nithi County, Kenya. The study asserted that remuneration has a great impact on productivity. Teachers' pay scale is generally very low compared to other professions and the civil service salaries. Since independence Kenyan teachers have gone on strike more than twelve times. The frequency of the strikes has increased since 1997 and has become an every year ritual. For instance, the teachers went on strike in October 1997, October 1998, October 2002, January 2009, March, 2010, September 2011, September 2012, and September 2013, and most recently in January 2015 (Borabu Sub County Education records, 2015). The reason for going on strike has been the demand for improved remuneration commensurate with that of other professions. The study established that the basic pay, allowances and work environment affects teachers job satisfaction, to a great extent. Evidence from studies have pointed that teachers were highly stressed with all aspects of compensation that they received due to work related variables on occupational stress which led to occupational stress among secondary school teachers and which prompted the present study. 
Table 1.1 Compared Teachers' Salaries with Civil Servants Salaries from July 2017.

Table 1.1: New teachers and civil servants salaries with effect from July, 2017.

New Teachers Salaries from July 1, 2017

\begin{tabular}{lllllll} 
JG Current & New grade & Minimum & Maximum & Grade & Minimum & Maximum \\
\hline \multirow{2}{*}{ P,Q,R } & D5 & 131,380 & 157,656 & E4 & 292,265 & 576,120 \\
& D4 & 118,252 & 141,891 & E3 & 244,020 & 309,906 \\
& D3 & 104,644 & 125,573 & E2 & 221,058 & 282,954 \\
& D2 & 91,041 & 109,249 & E1 & 198,267 & 257,747 \\
N & D1 & 77,840 & 93,408 & D5 & 150,202 & 198,267 \\
M & C5 & 62,272 & 77,840 & D4 & 132,178 & 174,475 \\
L & C4 & 52,308 & 65,385 & D3 & 114,334 & 152,064 \\
J & C3 & 43,154 & 53,943 & D2 & 97,184 & 130,226 \\
H & C1 & 27,195 & 33,994 & D1 & 81,148 & 109,550 \\
G & B5 & 21,756 & 27,195 & C5 & 64,919 & 91,148 \\
& & OBSOLETE & & C4 & 54,532 & 68,165 \\
& & & & C3 & 44,989 & 56,236 \\
& & & & C2 & 36,441 & 47,373 \\
& & & & B5 & 28,970 & 39,110 \\
& & & & B4 & 19,176 & 28,970 \\
& & & B2 & 16,778 & 24,823 \\
& & & & & 14,007 & 17,508 \\
& & & & 11,553 & 14,442 \\
\hline
\end{tabular}

Source: Education Magazine (2017).

Table 1.1 showed new salaries for teachers and civil servants which were to be effected in July 2017. Table 1.1 outlined civil servants earning a much higher salary compared to teachers at the same grade yet they work for the same government and the same government pays them. Such higher salaries for other professionals has increased discontent among teachers and increased occupational stress and turnover intentions. The intentions to turnover and the turnover itself can be interpreted as a protest against poor pay (Mutune \& Orodho, 2014). Therefore, it is not surprising that many teachers habour turnover intentions or quickly take up better paying opportunities as soon as they get one. Oyaro (2013) quoted data from KNUT which reported that between January and June 2008, more than six hundred secondary school teachers left teaching for other jobs citing poor pay accompanied by stressful work and conditions of service as the main reasons (Machio, 2011). Republic of Kenya / UNESCO (2012) end of a Decade evaluation of education in Kenya indicated that although the pupil teacher ratio at the national level and the country at large has achieved the recommended ratio of $45: 1$, there are still regional disparities especially in the Coast and Northern Eastern provinces where the pupil teacher ratio can be as high as 53:2 and 63:1 in 2013 respectively. The national teacher shortage stands at 61,235 for both primary and secondary schools (Republic of Kenya/UNESCO, 2012). Such a situation of teacher shortage increases the workload for the remaining teachers thus reducing their effectiveness. Other teachers combine teaching and other jobs mostly unrelated to teaching in an effort to increase income which negatively affects their performance in teaching. Thus the present study noted that there were various variables that influenced occupational stress among secondary schools teachers but selected some variables that influenced occupational stress among secondary school teachers of Borabu Sub County, Kenya. The selected work related variables identified included; role overload. Role overload involves situations where teachers indicate as having much work and feel overworked. Role ambiguity included situations where teachers have displayed confusion or conflict in the work they do since it is not well defined. Teachers find themselves in situations where they are required to multi task and finally they experience conflict in their work. In addition, they assert that promotions are limited indicating a slow career progression and that their employer does not appreciate the teachers efforts through promotions. Teachers compare their remuneration with the work they do and express dissatisfaction especially when they compare their salaries with workers in other professions resulting to teachers' occupational stress. These therefore are the selected work related variables which the current study undertook and their influence on occupational stress of secondary school teachers of Borabu Sub-County, Kenya. Role overload among teachers in Borabu Sub County has been identified as one of the factors influencing occupational stress among the teachers. The challenge of teacher shortage has been occasioned by most importantly teacher turnover where almost one in five teachers leave the profession in a given year (Emoja, 2016) and (Oduor, 2012). Kenya Secondary Schools Heads Association (KESSHA) decried the change of profession by teachers since it had seen schools loose an average of 600 teachers per year due to poor pay (Onwonga, 2012). Thinking of quitting is the most probable outcome of occupational stress (Zahra, Irum, Mir \& Chishti, 2013). Turn over intentions are evidenced by Kenya National Union of Teachers (KNUT) and 
Kenya Union of Post Primary Education Teachers (KUPPET) frequent strikes for salary increases for their members (Gathungu \& Wachira, 2013). A brief by Kenya Secondary Schools Heads Association (KESSHA, 2016) allegedly indicated that an average of 23 secondary principals die every year due to stress related complications (Daily Nation, $29^{\text {th }}$ June, 2016). The report further indicated that $67 \%$ of the principals' deaths were as a result of heart attacks, high blood pressure, hypertension and other ailments triggered by stress. The then national chairman indicated that in the last six years the number of principals who had died due to stress had been increasing and in the year 2016, 14 Principals died due to excessive stress at work. In addition, the report indicated that most of the victims suffer serious medical conditions because of working long hours and days without adequate rest. Further, the report observed that the nature of the job was so demanding and put so much pressure on the principals. It was also noted that the reforms in the Education ministry, the Teachers Service Commission, expectations from the society and the changing environment of the learners bring so much stress to school principals and teachers as there was pressure exerted on them to produce academic excellence and implement government educational reforms which took toll on the health of principals and teachers. Occupational stress in Kenya has not been satisfactorily researched and some researchers who have studied occupational stress have largely considered either factors causing or contributing to occupational stress or occupational stress, job satisfaction and burnout (Wangeri \& Okello 2013, Wangui et.al 2016, Sichambo et.al, 2012). There is lack of sufficient empirical evidence on selected work related variables and their influence on occupational stress among secondary school teachers of Borabu Sub County, Kenya.

The present study noted that there was a knowledge lacuna and purposed to bridge it. According to Borabu Sub County Human Resource report (2018), principals of high schools in Borabu Sub County reported complaints, indicators and manifestations of teacher stress exhibited by high school teachers to include : absenteeism, early exit to private sector, turnover intentions, drunkenness or use of drugs, over borrowing from credit facilities and banks, running of private businesses and moonlighting, non-commitment to the profession or low morale, low efficiency and even productivity. Further, complaints of persistent migraine and headache were observed by some of the teachers, death of some teachers, role overload, lack of career advancement and promotions, aggressive behavior towards colleagues and students, active participation in strikes, poor physical and emotional health and depressive moods were also experienced. In addition, there was reduced creativity, low productivity, low selfesteem, existence of early stages of burnout, early retirement, long hours of lesson preparation, marking and paper work, increased demands from administrative duties, limited relaxation time with long syllabuses and assessment requirements, disappearance of teacher authority, lack of job satisfaction, meeting TSC demands of filling staff performance appraisals to be among the reasons for experiencing occupational stress. Available data of high school teacher shortage in Borabu Sub County was at 120 teachers (Borabu Sub County human resource officer, 2018) which occasioned role overload.

Moreover, according to Borabu Human Resource Office (2018), shortage of teachers was enhanced by among other reasons occupational stress which led to turnover, early retirement, teachers requesting for sick leave because of sickness as a result of stressful work and natural attrition. Further, in Borabu Sub County, between the year 2015 to 2018, 40 teachers left for early retirement, 100 teachers were out of school after seeking sick leaves and 50 teachers were recommended to go for rehabilitation out of drunkenness. The drunkenness was occasioned by the teacher's expression of pressure at work. In addition, 50 teachers had borrowed heavily from various credit facilities and were being sought and the complaint was received by the principals, 20 teachers had mysteriously died and 5 teachers committed suicide (Borabu Sub County Education Office, 2018). Various research studies have concentrated on factors that contributed to occupational stress and stress management strategies among teachers but have not considered influence of selected work related variables on occupational stress. This gave a justification of the need for the study hence, acknowledge gap which the study has filled on the influence of selected work related variables on occupational stress among secondary school teachers of Borabu Sub County. In Borabu Sub-County, there have been reported cases of teachers suffering occupational stress due to inadequate salary, work overload, time constraints, lack of promotion opportunities, changing job roles, inadequate management and participation in management decision making, inadequate resources and funding, inadequate policies and student indiscipline (Borabu Sub County Office, 2018). Similarly, there have been reported cases of secondary teachers in Borabu Sub County faced with stress building situations in their day to day engagements resulting in under productivity. From the year 2015 to 2018, 50 secondary school teachers left for early retirement, some other 50 teachers left teaching for other lucrative jobs, over 100 teachers sought permission for sick leaves even for minor ailments, 50 teachers were recommended for rehabilitation and went to seek help at rehabilitation facilities, 50 teachers were reported to have heavily borrowed from credit facilities, 20 teachers mysteriously died while 5 teachers committed suicide and several others engaged in moonlighting activities besides their teaching job ( Borabu Sub- County Human Resource Office, 2018). Various studies by other researchers have considered factors causing or contributing to occupational stress among teachers and stress management strategies in Kenya but have not investigated the influence of selected work related variables on occupational stress among secondary school teachers of Borabu Sub County. The present study therefore noted that there was need to 
investigate the influence of selected work related variables on occupational stress among teachers of public secondary schools in Borabu Sub County. The purpose of this study was to determine the influence of role overload on occupational stress among public secondary school teachers in Borabu Sub- County, Kenya and guided by the following hypothesis. Ho1 There is no statistically significant influence of role overload on occupational stress among public secondary school teachers in Borabu Sub County, Kenya.

\subsection{Literature Review}

Boyland (2011) in a study on job stress and coping strategies of elementary principals; a statewide study in USA found that a large majority of Indiana's elementary principal participants are experiencing moderate to high levels of job stress. Additionally, most of the experienced principals indicate more stress now than in previous years. A total of 193 principals from 79 Counties in Indiana responded to the survey. Further, Kales (2014) examined the relationship between occupational stress and job success or failure. The target population comprised of teachers of colleges affiliated to Jammu University, Kashmir. The study did not report the research design employed. The sample size consisted of 100 male and female teachers from professional colleges of education in Kashmir who were selected by simple random sampling technique. The study adopted the Occupational Stress Scale developed by Srivastava and Singh as the major data collection instrument. The findings of the study suggested that work overload was among the factors that significantly elicited occupational stress among male and female workers in an organization. A study in Pakistan by Warraich, Ahmed \& Khoso (2014) aimed at determining the impact of stress on job performance by employees. Empirical research was done on 133 employees of private sector's Universities in Karachi, Pakistan that are providing education in the disciplines of Business Admnistration, Engineering, Medicine, Textile and Fashion. Pertinent data was collected through questionnaires based on closed ended questions. The results obtained from the data revealed that workload and role conflict and in adequate monetary reward are the prime reasons of causing stress on employees and this stress reduces their efficiency. Thus it was recommended that employers should minimize stress by lowering the workload, abate the role conflict, pay adequate salary and provide training and counseling to employees in order to improve their job performance and job satisfaction. In another study Sharma (2008) conducted a study to identify levels of stress and associated factors in Rajastan. The study adopted a cross sectional survey research design. The target population was secondary school teachers of Karauli district in Rajastan. The sample size of 15 public and 25 private schools was selected using simple random sampling technique. The sample size of 350 respondents was obtained using cluster sampling technique. Study findings revealed that work load was significantly associated with occupational stress. The study recommended that the government should institute immediate policy interventions to control stress among teachers and that further studies should be conducted to gather more information about work overload as a stressor and the best ways to mitigate the issue. Sing \& Katoch (2017) carried out a study of occupational stress of secondary school teachers of Mandi District, India. It was found that secondary school teachers generally had high, moderate and low levels of stress. Additionally, Anbu (2015) conducted a study on professional stress of higher secondary school teachers in and around Nagercoil region and observed that the female higher secondary school teachers have more stress than the male higher secondary school teachers. The reason is that the female teachers apart from guiding the terminal stage of school students, they have to look after their family members, they were not able to allocate equal weight to working as well as family environment, hence this resulted in enhanced stress level.

Married higher secondary school teachers have more less stress than the unmarried since the married higher secondary teachers have more responsibility than the unmarried in terms of school work as well as in the family and society, hence they are in the position to satisfy all the dimensions resulting in higher levels of stress. Similarly, Lokanadha and Vijaya (2013) examined occupational stress of teachers working at higher secondary level. The researchers asserted that some measures which could prove beneficial to teachers in coping with stress include; improving self esteem, build self confidence, work on building emotional intelligence competencies, develop a good sense of humour, practice yoga and meditation, exercise regularly, foster a supportive friend circle, cultivate hobbies, develop effective communication skills, and seek professional help if necessary. Masuku \& Muchemwa (2015) studied occupational stress among lecturers in Zimbabwe, a case of Solusi University. While the study explored stress levels, symptoms and common stressors for lecturers at Solusi University, the present study concentrated on influence of selected work related variables and their influence on occupational stress among secondary school teachers. The study findings revealed that most of Solusi University lecturers are stressed and others exhausted as indicated by a frequency of $50 \%$. The findings revealed that the most common stressors were increased workloads, need to hit targets or deadlines and long working hours. Manabete, John, Makinde and Duwa (2016) sought to examine stress, job or vocational and workplace stress among school administrators and teachers in Nigerian secondary schools and technical colleges. The study identified role ambiguity, poor relations with boss, work overload, thwarted ambition and job insecurity as workplace sources of stress. The paper holds that teachers' lives are often gravely affected by stress which leads to physical ill-health such as headache, stomach upset, aches and pains. Severe and unchecked stress leads to severe ill conditions like high blood pressure, diabetes, stroke and 
heart disease. In critical cases, stress can lead to death. The paper identifies wrong ways to deal with stress to include smoking, using pills or drugs to relax, too much drinking of alcohol and other intoxicating drinks, filling up every minute of the day with activities in order to avoid problems, oversleeping, and transferring one's stressful condition on others. In another study in Swaziland by Caesar, Dlamini, Chinedu and Kuttickattu (2014) sought to investigate work related stress among high school teachers in the Hhohho region of Swaziland. Study sample comprised of 291 teachers coming from 10 randomly selected high schools in the Hhohho region of Swaziland but the present study involved 236 respondents. Empirical studies conducted in Nigeria by Salami, Ojokuku and Ilesnami (2010) also found that stress was negatively correlated to performance. Counseling at the work place and stress reduction workshops were some of the interventions identified. A similar study in South Africa by Jonker (2016) was carried out to identify levels of stress overload and to investigate its relationship with specific correlates and predictive variables among lecturers. Results of the multiple linear regression analysis indicated that organizational constraints, interpersonal conflict at work and distress tolerance were significant predictors of stress overload. The study contended that the main factors contributing to teachers' stress and teachers leaving the profession are workload, problems in the classroom, organizational contexts (such as lack of material and facilities) and interpersonal conflicts. Observation was made from the study that the end result of teacher stress is that many talented men and women with high expectations of achievement are dispirited and disillusioned. Some leave the profession while those who remain are plagued by a multitude of physical, emotional and behavioral stress related manifestations. In addition, Kabunga and Muya, (2014) investigated work stress and coping strategies among social workers in Uganda. The study adopted a descriptive cross-sectional survey research design. The study findings revealed that most respondents had high stress levels caused by work demand among other variables.

Separately, Mwakasangula \& Mwita (2020) did a study to examine the relationship between occupational stress and job satisfaction among teachers in Tanzania public secondary schools. The study findings revealed that stress related to working environment $\mathrm{p}=.001$, stress related to leadership $\mathrm{p}=0.15$ and stress related to workload $\mathrm{p}=.042$ have a significant relationship with job satisfaction. Two control variables; gender (female, $\mathrm{p}=.000$ ) and education level $(\mathrm{p}=.046)$ were also found to have a significant negative relationship with job satisfaction while age $(\mathrm{p}=.004)$ were found to have a significant positive relationship. The study recommended provision of leadership training to heads, deputy heads and all people holding leadership positions in public primary schools, employing more teachers in schools, allocation of manageable workloads to teachers and improvement to teachers working environment to help them increase job satisfaction. In the same breath, Jamilu (2015) conducted a study on stress management among secondary school teachers in Mbale Munincipality, Uganda. The study focused on various causes of stress among teachers, levels of stress among teachers, comparing stress among teachers based on demographic variables and the attendant coping mechanisms employed by the same teachers. The results showed that teachers are stressed by heavy paper work or prep work, low salaries, students' indiscipline and poor working environments with low salaries as the major causes of stress among the secondary school teachers. Study findings revealed gender differences in the levels of stress. In addition, the findings also revealed that educational qualifications of teachers differ statistically in terms of their stress level. The study further found that teachers in Mbale Munincipality used different coping mechanisms in reducing stress. In addition, Mengistu (2012) investigated factors that influence job satisfaction of secondary school teachers. The results indicated that teachers were dissatisfied with most aspects of their work. Salary and benefits emerged as the primary dissatisfying aspect of all the work factors. Other areas of dissatisfaction related to poor fringe benefits and opportunities for promotion, management style of the principals, lack of decision making opportunities for the teachers as well as the opportunity to develop personally and the poor relationship teachers have with the principals and parents. The study also found that teachers who were fifty years and older were significantly satisfied with their work than the younger teachers. Accordingly, teachers with 21 years and more experience were also significantly more satisfied with their work than the less experienced teachers. Poipoi (2011) conducted a study to identify the factors contributing to stress among teachers of public secondary schools in Vihiga District. The study employed descriptive research design. Questionnaires and interview schedules were used as instruments by the study to collect data. Stratified random sampling was employed and the sample size of the study was 16 teachers. The study findings were that stress was caused by heavy workload, lack of clarity on the duties and responsibilities, poor management, substandard equipment and insufficient salaries. The effects of stress included poor relations with students and administration, lack of unity, absenteeism, loss of motivation and teacher transfer. Macharia (2015) did a study on institutional factors influencing occupational stress of academic governors in secondary schools of Dagoretti Subcounty and asserted that workload is one of the greatest complaints by academic governors as they have to balance both administrative roles and compliance of work. Academic governors were also expected to teach. The study further observed that academic governors experience workload pressure making their working hours spill to their personal time and social time hence the administrators are burned out resulting to anger and frustration as the workload increases and pressure to perform and finish this work increases. It adversely impacts on educational out comes thus leading to occupational stress. Further, Wang'eri \& Okello, (2014) investigated factors related to work among primary school teachers. Study findings revealed that most teachers reported work 
overload with a significant relationship between work overload and burn out. The study further revealed that teachers in public schools experienced higher work stress than those in private secondary schools. Additionally, Gitonga and Ndagi (2016) conducted a study on the influence of occupational stress on teachers' performance in public secondary schools in Nyeri South Subcounty and contended that the main cause of occupational stress was workload. Increasing the workload in an organization without taking into account the availability of staff to carry out the task is a major stress factor among employers in various organizations. Severally, employees found themselves in a position where work had to be taken home to fulfil and sustain professional standards. Such extra work reduced the opportunity for restorative psychological detachment from the job. The study further asserted that teachers are responsible for so many activities other than teaching and these includes planning, marking of internal examinations, writing reports, ensuring cleanliness, maintaining discipline in class and outside class, supervising meals as well as attending to co-curricular activities. Teachers thus deal with time pressure and occupational stress. Similarly, Nyagaya (2015), sought to find out workload and teachers levels of job satisfaction in Kayole Division of Embakasi district in Nairobi. The study noted that teachers deal with workload which is too heavy and deadlines that are impossible to reach and this makes it stressful to them. This caused job satisfaction to erode even to the most dedicated employee. Being unable to beat deadlines result in conflicts between employees and supervisors and this also causes a lot of stress among workers in any organisation. Additionally, the study observed that understaffing of teachers in most public primary schools especially in Kayole division has a positive relationship with the poor morale and despair among teachers which has the effect of lowering the quality and relevance of education. In a related study, Waithanji (2014) did a study on impact of teacher burnout in secondary schools in Mathira East District, Kenya. The study recommends that solutions to student discipline should be reached in order to reduce teacher burnout resulting from discipline related issues within the school. The researcher also recommends that the schools should develop appropriate strategies to improve the level of interpersonal relations among the teachers, other staff and students in order to reduce teacher burnout resulting from negative attitude and interpersonal relations in the workplace. On a similar note, Juma, Simatwa and Ayodo, (2016) did a study on factors influencing stress among public secondary school female principals in Kenya; A case study of Rachuonyo North and Homabay Sub-counties. The study observed that the female principals indicated that high professional and societal demands and expectations have made them to experience stress. Stress is experienced due to low performance of students' examinations in the schools headed by the female principals. The study established that female principals in Rachuonyo North and Homabay Sub Counties were experiencing moderate stress. The factors that had highest influence on their stress included working environment, pursuit for excellence, conflicting demands from stake holders, lack of time to teach and attend to administrative tasks, workload, uncertainity in job expectations, indisciplined teachers and staff shortage. In addition, Manduku, Koech and Chepkirui (2016) undertook to study stress management strategies and their effects on teachers' commitment in primary schools in Sabatia District, Kenya. The study findings indicated that majority of the teachers believed that teachers self efficacy contributed to teachers' job satisfaction. There was need for education stakeholders in the district and the country at large to devise ways of making teachers to be committed to their work and stay more in the teaching profession and at the same time there was need for the government to employ more teachers in public primary schools to reduce teacher workload which has been shown to increase teacher stress. In a related study Baraza, Simatwa and Gogo (2016) carried out a study on levels of stress among secondary school teachers and its implication on students academic performance in Kenya: A case study of Kakamega North Sub County. The study established that $6.06 \%$ of the teachers recorded low levels of stress, $37.7 \%$ recorded moderate levels of stress and $56.7 \%$ recorded high level of stress. These results implied that students' performance in the Sub County may be low because only $37.7 \%$ of teachers recorded moderate stress levels that are associated with better performance. Low and high levels are bound to lead to low productivity. It was apparent from the reviewed studies that some of the studies used small sample size making it difficult to generalize the results, hence the present study used a larger sample to ensure the findings are representative. Some studies used case studies which were subjective in relation to the results, however the present study used probability sampling techniques to ensure objectivity was achieved.

\section{RESEARCH METHODOLOGY}

The present study employed convergent parallel research design within mixed methods approach to take advantage of the availability of all data collection procedures, address questions that could not be addressed by either quantitative through questionnaires or qualitative research through interviews only in order to benefit from the advantages of mixing and triangulating research findings (Creswell, 2014). The design involved collection of different but complementally data on the same phenomena but analyzed individually. The target population for this study comprised all secondary school teachers of all public secondary schools within Borabu Sub County. The study employed all the 212 public secondary school teachers , 21 principals of all the 21 public secondary schools of Borabu Sub County, and 3 Borabu Sub County Education Officers who included the Sub County Director of Education, the TSC Sub County Director and the Sub County Human Resource Officer. Borabu Sub 
County was selected because no known study of this kind has been done, and the education productivity is not one of the best as witnessed by the results posted in the Kenya Certificate of Secondary Examination in Borabu Sub County. The present study used saturated sampling. Thus the study utilized $100 \%$ of all the respondents as a sample. Questionnaires and interviews were the main data collection instruments. The questionnaire contained both open- ended and closed-ended questions in order to collect quantitative data.

\section{RESULTS AND DISCUSSION}

The main objective was to investigate the influence of role overload on occupational stress among public secondary school teachers in Borabu Sub County, Kenya. The objective was addressed by using; descriptive statistics, to explore the level of role overload among the teachers and inferential statistics, to test the hypothesis.

\section{Table 1.2: Percentage Frequency and Mean Responses on Role Overload Items}

\begin{tabular}{|c|c|c|c|c|c|c|}
\hline & & SD & D & $\mathbf{N}$ & $\mathbf{A}$ & SA \\
\hline 1 & $\begin{array}{l}\text { I always carry my work home to complete } \\
\text { it at night }\end{array}$ & $34(18.1 \%$ & \%) $21(11.2 \%)$ & 6) $18(9.6 \%)$ & $65(34.6 \%)$ & $50(26.6 \%$ \\
\hline 2 & $\begin{array}{l}\text { I have to neglect some tasks because I } \\
\text { have too much to do }\end{array}$ & $15(8.0 \%)$ & $29(15.4 \%)$ & $26(13.8 \%)$ & $56(29.8 \%)$ & $62(33.0 \%$ \\
\hline 3 & $\begin{array}{l}\text { I am subject to personal harassment at } \\
\text { work (see definition in introduction). }\end{array}$ & $41(21.8 \%)$ & $31(16.5 \%)$ & $8(4.3 \%)$ & $48(25.5 \%)$ & $60(31.9 \%)$ \\
\hline 4 & $\begin{array}{l}\text { My stress increases when working under } \\
\text { deadline pressures and pressure to } \\
\text { produce better exam results }\end{array}$ & $15(8.0 \%)$ & $28(14.9 \%)$ & $19(10.1 \%)$ & $53(28.2 \%)$ & $73(38.8 \%)$ \\
\hline 5 & $\begin{array}{l}\text { I have to work very intensively to } \\
\text { accomplish my work. }\end{array}$ & $8(4.3 \%)$ & $13(6.9 \%)$ & $17(9.0 \%)$ & $82(43.6 \%)$ & $68(36.2 \%)$ \\
\hline 6 & $\begin{array}{l}\text { I find myself thinking about the work I do } \\
\text { when I am supposed to be relaxing }\end{array}$ & $15(8.0 \%)$ & $24(12.8 \%)$ & $22(11.7 \%)$ & $77(41.0)$ & $50(26.6 \%)$ \\
\hline 7 & $\begin{array}{l}\text { I have to neglect some tasks because of } \\
\text { too much work to do. }\end{array}$ & $19(10.1 \%)$ & $17(9.0 \%)$ & $20(10.6 \%)$ & $63(33.5 \%)$ & $69(36.2 \%)$ \\
\hline 8 & $\begin{array}{l}\text { I experience increase in muscular aches } \\
\text { and pains especially in the neck, head, } \\
\text { lower back and shoulders }\end{array}$ & $22(11.7 \%)$ & $19(10.1 \%)$ & $19(10.1 \%)$ & $54(28.7 \%)$ & $74(39.4 \%)$ \\
\hline 9 & $\begin{array}{l}\text { I do not have time for many interests and } \\
\text { hobbies outside work }\end{array}$ & $17(9.0 \%)$ & $43(10.1 \%)$ & $26(13.8 \%)$ & $64(34.0 \%)$ & $62(33.0 \%)$ \\
\hline 10 & $\begin{array}{l}\text { Dealing with larger classes and many } \\
\text { students has increased my workload }\end{array}$ & $8(4.3 \%)$ & $30(16.0 \%)$ & $23(12.2 \%)$ & $64(34.0 \%)$ & $63(33.5 \%)$ \\
\hline 11 & $\begin{array}{l}\text { I am not able to take sufficient breaks } \\
\text { from my work. }\end{array}$ & $23(12.2 \%)$ & $18(9.6 \%)$ & $34(18.1 \%)$ & $59(31.4 \%)$ & $54(28.7 \%)$ \\
\hline 12 & $\begin{array}{l}\text { I often lack time to pay attention to each } \\
\text { special needs of each student }\end{array}$ & $23(12.2 \%)$ & $29(15.4 \%)$ & $18(9.6 \%)$ & $68(36.2 \%)$ & $50(26.6 \%)$ \\
\hline 13 & I am forced to work long hours. & $16(8.5 \%)$ & $31(16.5 \%)$ & $19(10.1 \%)$ & $60(31.9)$ & $62(33.0 \%)$ \\
\hline 14 & $\begin{array}{l}\text { I feel overwhelmed by changes in } \\
\text { curriculum, school organization, } \\
\text { instructional methods and assessment } \\
\text { techniques /staff appraisal in my teaching }\end{array}$ & $17(9.0 \%)$ & $15(8.0 \%)$ & $34(18.1 \%)$ & $69(36.7 \%)$ & $53(28.2)$ \\
\hline 15 & $\begin{array}{l}\text { I have to work very fast to hit my school } \\
\text { targets and deadlines }\end{array}$ & $6(3.2 \%)$ & $6(3.2 \%)$ & $11(5.9 \%)$ & $90(47.9 \%)$ & $75(39.9 \%)$ \\
\hline 16 & $\begin{array}{l}\text { My job makes it difficult to maintain the } \\
\text { kind of personal life that I want }\end{array}$ & $16(8.5 \%)$ & $38(20.2 \%)$ & $32(17.0 \%)$ & $56(29.8 \%)$ & $46(24.5 \%)$ \\
\hline 17 & I have unrealistic time pressures. & $16(8.5 \%)$ & $42(22.3 \%)$ & $28(14.9 \%)$ & $56(29.8 \%)$ & $46(24.5 \%)$ \\
\hline 18 & $\begin{array}{l}\text { I am always asked to work on assignments } \\
\text { that are not necessarily to the profession }\end{array}$ & $26(13.8 \%)$ & $33(17.6 \%)$ & $19(10.1 \%)$ & $68(31.9 \%)$ & $50(26.6 \%)$ \\
\hline
\end{tabular}

\section{Source: Survey data (2018)}

Table 1.2, demonstrates the means and percentages of work load of teachers in public secondary schools in 
relation to role overload. The evidence showed majority of teachers strongly agreed that they are heavy role overload. To investigate whether there was any statistical significant influence of role overload on occupational stress among public secondary school teachers, the null hypothesis was tested. Table 1.3 shows a correlation analysis output between Role Overload and Occupational Stress among Public Secondary School Teachers.

Table 1.3: Correlation between Role Overload and Occupational Stress among Public Secondary School Teachers

\begin{tabular}{llll}
\hline & & \multicolumn{1}{c}{$\begin{array}{c}\text { Role } \\
\text { overload }\end{array}$} & $\begin{array}{l}\text { Teacher Occupational Stress } \\
\text { Role overload }\end{array}$ \\
& Pearson Correlation & 1 & $.647^{* *}$ \\
& Sig. (2-tailed) & & .000 \\
& N & 188 & 188 \\
Teacher Occupational Stress & Pearson Correlation & $.647^{* *}$ & 1 \\
& Sig. (2-tailed) & .000 & \\
& N & 188 & 188
\end{tabular}

**. Correlation is significant at the 0.01 level (2-tailed).

The null hypothesis stated there was no statistical significant influence of role overload on occupational stress. The null hypothesis was rejected since it was established that there was a statistically significant positive relationship between role overload and occupational stress among public secondary school teachers. From the results, a Pearson's correlation Coefficient of $\mathrm{r}=0.647$ was established. This shows that role overload influences occupational stress among the teachers. The correlation analysis established a fairly strong positive $(\mathrm{n}=188, \mathrm{r}=.647$; $\mathrm{p}<.05)$ correlation between role overload and occupational stress among public secondary school teachers, with higher role overload associated to higher teacher occupational stress levels, as indicated in the SPSS output in Table 4.4. Hence, from these findings it was concluded that there is statistically significant positive relationship between role overload and occupational stress among public secondary school teachers. Similarly, Kales (2014) study in Kashmir suggests that work overload was among the factors that significantly elicited occupational stress among teachers of Jammu University. Boyland (2011) study in U.S.A. found out that a large majority of Indiana's elementary principals experienced moderate to high levels of job stress. However, Chang and Lu (2009) study revealed significant differences across occupations with teachers experiencing the least work stressors and civil servants experiencing the most work stressors.

Further, to estimate the level of influence of role overload on occupational stress among public secondary school teachers, a coefficient of determination was computed using regression analysis and the result was as shown in Table 1.5

Table 1.5 Regression Results- Influence of Role Overload and Occupational Stress among Public Secondary School Teachers

\begin{tabular}{lllll}
\hline Model & $\mathrm{R}$ & $\mathrm{R}$ Square & Adjusted R Square & Std. Error of the Estimate \\
1 & $.647^{\mathrm{a}}$ & .419 & .416 & \\
\hline
\end{tabular}

a. Predictors: (Constant), Role overload

b. Dependent Variable: Teacher Occupational Stress

It is evident from Table 1.5 that the level of role overload accounted for $41.6 \%$, as signified by coefficient of Adjusted $\mathrm{R}^{2}=.416$, of the variation in occupational stress among public secondary school teachers. This finding implies that variation in the level of role overload explains about $42 \%$ of the variability in occupational stress among public secondary school teachers. This is a fairly large influence on a dependent variable by one predictor, hence, it reveals the importance of controlling teachers' work load in order to reduce occupational stress. This signifies that the null hypothesis that: "There is no statistically significant influence of role overload on occupational stress among public secondary school teachers in Borabu Sub County, Kenya", was rejected. It was therefore concluded that there is statistically significant positive influence of role overload on occupational stress among public secondary school teachers in Borabu Sub County, with high level of role overload associated to occupational stress among public secondary school teachers and vice-versa. Based on the findings, the study established that there was a statistically significant relationship between role overload and occupational stress of secondary school teachers. A Pearson correlation was obtained which denoted that role overload influenced occupational stress to a large extent. It was observed that teachers were multi-tasking in their work. A conclusion was drawn that there was a positive significant relationship between role overload and occupational stress among secondary school teachers. Therefore, the study recommended that there was need to increase the human resource to lower the load on the teachers who are already burdened and experiencing occupational stress.

\section{REFERENCES}

Anbu, A. (2015) professional stress of higher secondary school teachers.International journal of multidisciplinary research and development $2(1) ; 1-3$

Baraza, O.T, Simatwa E.M.W, Gogo, O.J. (2016). Levels of stress among secondary school teachers and its 
implication on students academic performance. Acase study of Kakamega North SubCounty.Greener Journal of Education and Research.ISSN $2276-7789$

Caesar,S.D.,Chinedu, I.O.O, Kuttickattu,J.M (2014) An Investigation of Work -Related Stress among High School Teachers in the Hhoho Region of Swaziland.Mediterranean Journal of Social Sciences.Vol.5. No.5. MCSER Publishing,Rome-Italy

Cohen, L. \& Manion, L. \& Morrison,K. (2007). Research Methods in Education. London : Routledge Publishers.

Creswell, J.W. (2014). Research Design: Qualitative, Quantitative and Mixed Method Approaches. Thousand Oaks, CA: Sage

Boyland, L. (2011). Job stress and coping strategies of elementary principals: A statewide study. Current Issues in Education vol. 14 (3):1-11.

Gitonga, M. K. \& Ndagi, J.M. (2016) Influence of occupational stress on Teachers performance in public secondary schools in Nyeri County, Nyeri Subcounty, Kenya. International Journal of Business and Management Invention.May, 2016, pp 23-29.

Henn, M., Weinstein, M.\& Foard, N. (2006). A short Introduction to Social Research. New Delhi: Sage Publications Inc.

Hessie-Biber, S. N. (2007). Handbook of Feminist Research: Theory and Praxis. Thousand Oaks: Sage.

Jamilu, H. (2015) Stress Management among Secondary School Teachers of Mbale Munincipality (Uganda) https:ir.iuiu ac.ug -Islamic University of Uganda.

Jonker, L.C. (2016) Stress in college workplace and its relationship with certain coorelates and predictive variables . (Masters Thesis)https://scholar.sun.ac.za.

Juma, Simatwa \& Ayodo. (2016). Factors influencing Stress among Public Secondary Schools Female Principals in Kenya; A case study of Rachuonyo North and Homabay Sub Counties. Educational Reseach Vol7(2) ,pp041-054,April 2016.

Kabunga, A. \& Muya, F.M. (2014) Work Stress and Coping Strategies among Social Workers: A case of Northern Uganda. International Journal of Liberal Arts and Social sciences, 2(8): 33-38.

Kales, M. Z. (2014). Occupational Stress among Teachers: A Study of the Professional Colleges of Education in Jammu, Province of J\&K State. Scholarly Research Journal for Interdisciplinary Studies, 2(12): 1445-1469.

Lokanadha, R. \& Vijaya, A. (2013) Occupational stress of higher secondary school teachers in Vellore district.Internatinal Journal of Educational planning \& administration. Vol (13) pg 9-24 . London: Sage.

Macharia,G.W. (2015) Institutional Factors Influencing Academic Governors Occupational Stress in Secondary Schools in Dagoreti Subcounty, Kenya. Un pubished Masters Thesis. Nairobi University.

Manduku. J, Koech, Z. \& Chepkirui, P. (2016) Stress Management Strategies and their effect on teacher commitment in primary schools in Sabatia District,Vihiga County. Educational Research Journal vol.6, Jan.2016

Manabete,S.S., John,C.A.,Makinde, A. A.\& Duwa,S.T. (2016) Job Stress among School Administrators and Teachers in Nigerian Secondary Schools and Technical Colleges. International Journal of Education, Learning and Development. Vol.4,No.2,pp1-9

Masuku, S. \& Muchemwa,S.(2015) Occupational Stress among University Lecturers, A case of Zimbabwe. US China Education Review .Vol 5, No.4. pg 258-266

Mengistu, G.K.(2012) Job Satisfaction of Secondary School Teachers in Ethiopia.Un published Phd Thesis.University of South Africa, South Africa.

Mwakasangula, E. \& Mwita, K.M. (2020) Relationship between Occupational Stress and Job Satisfaction among Teachers in Tanzania Public Primary Schools. Journal of Cooperative and Business Studies.ISSN 27142043 .Vol. (5),Issue (1),2020.

Nyagaya, P.A (2015) Factors influencing Teachers level of Job Satisfaction in Public Primary Schools in Kayole Division, Embakasi County, Kenya. Un published Masters Thesis.

Poipoi, C.A. (2011) Factors Contributing to Stress among Public Secondary School Teachers in Vihiga District. International Journal of Current Research.

Waithanji, G.W. (2014). Impact of Teacher Burnout in Secondary Schools in Mathira East District, Kenya. Karatina University.http:karu space.karu.ac.kel

Wangeri, T. \& Okello, W. L. (2014). Role Overload Teacher-Pupil Ratio, Schools Type, Years of Teaching Experience, Gender and Burn Out as Factors Related to Work Stress Among Primary School Teachers in Kasarani Division, Nairobi County, Kenya. Global Journal of Human- social science: G Linguistics \& Education, 14(1): 195-202.

\footnotetext{
1.Author Lucy Kemunto Omwenga *Jaramogi Oginga Odinga University of Science and Technology .School Of Education

2. Dr. Judith Owaa. Jaramogi Oginga Odinga University of Science and Technology. School of Education, Department of Psychology and Educational Foundations.
} 